\title{
A Chronology of the Founders of the Forceps (1569-1799).
}

\author{
By Alban Doran, F.R.C.S., \\ Consulting Surgeon to the Samaritan Free Hospital.
}

THE following chronological epitome of the obstetricians who introduced and established the obstetric forceps is compiled from the works of Mulder, Smellie, Aveling and others, books not accessible to every medical reader and never, as I can testify, to be found together in the same library in London, Edinburgh or Dublin. It will aid the obstetrician and literary doctor in gaining a fair notion of the dates which throw light on the gradual evolution of the forceps. When the earlier writings, noted throughout this epitome, are consulted, the reader will be able to discover with little difficulty the development of other instruments such as the vectis, the perforator and the cephalotribe. Lost history, of course, cannot be rewritten, and therefore the precise relation of Smellie to the adoption and modification of the forceps is not likely to be thoroughly cleared up, unless some reliable but hitherto undiscovered documents can be found and published. We must all be deeply grateful to Dr. Alfred McClintock who did such excellent work in that direction in his New Sydenham Society's edition of Smellie's "Treatise." For my own part, however, I have availed myself of the second edition published in 1779 , and always consulted the original writers in making references, whenever possible.

I have appended the genealogy of two illustrious obstetric families, the Chamberlens and Baudelocques. Though much has been written concerning the former, there is great confusion about their relationship, due to more than one bearing the same Christian name, whilst there is considerable misapprehension in respect to the Baudelocques, many of us being under the impression that there was but one, or at least one father and one son, of that name associated with obstetrics, whilst the initial Christian names have been sometimes misprinted in British and German works. Aveling's "The Chamberlens and the Midwifery Forceps" has been my standard work of reference for the "Asclepiad family," while for the genealogy of the Baudelocques I am indebted to Professor Paul Bar.

I569. William Chamberlen leaves France and lands at Southampton, attending at the Church of St. Julian, according to the custom of Huguenot refugees, on landing. "Chambrelein Villame, reçu à la Cène, 3 Juillet ${ }^{1569 . " ~ H i s ~ w i f e ~ a n d ~ h i s ~ t h r e e ~}$ 
children, Peter (the elder), Simon, and Jane came with him, and a son "Jacques fils de Villame Chambrelein et de Genevieve Vingnon sa fâme" baptized July 26 th.

1572. Birth of Peter the younger, son of William. Peter, the elder brother, was old enough to attest to the birth and baptism of his brother (Aveling, l. cit., p. 15). 1588. Peter the elder still in Southampton. 1596. In a legal document his residence is given as London and "the late William Chamberlaine" is referred to. The actual date of William's death is not recorded, nor is it known in what year Peter the elder joined the Barber Surgeons (see 1598).

1596. Peter the younger admitted in this year, or shortly after, to the Company of Barber Surgeons. The deposition of his birth in England in 1572 was again officially recorded before the Vicar. General of the Bishop of London, to satisfy the Barbers' Company that he was not born abroad (Aveling, l. cit., p. 17).

1598. Peter the elder's name appears in the "Annals of the Barber Surgeons' Company." He must have received the hood before ${ }^{1598}$, when he was cited before the Court for "arrerages of his debts for his admission." During the succeeding years he more than once paid fines for absence from lectures, being in good practice.

1600. Peter Chamberlen the younger was licensed to practise midwifery by the authority of the Bishop of London in this or in the preceding or succeeding year (Aveling, l. cit., pp. 18, i9).

1601. Birth of Dr. Peter Chamberlen, son of Peter the younger.

1602. The "Annals of the Barber Surgeons" report "August 3. This daye Peter Chamberlen (sic) the younger fyned for his absence from lectures and upon his humble suit he was admitted to hang out his bassins for Barbour in Blackfryars." Already in I600 he had been accused by the College of Physicians of having treated Morbus Gallicus by means of purging and drying diet. He was repeatedly in trouble, both with the College and with the Barber Surgeons, for professional irregularities (Aveling, l. cit., pp. 17-24).

1609. "Petrus Chamberlaine Senior habitans in Marke Lane," cited before the President and Censors of the College of Physicians for practising physic instead of confining himself to surgery ( $I b$., p. 6).

1612. After repeatedly transgressing in the manner as in 1609 , Peter the elder was imprisoned in Newgate. He was set free after great resistance from the College. The Archbishop of Canterbury, at the mandate of the Queen, Anne of Denmark, prevailed with the President of the College and Peter was released. In his will, Peter the elder refers to "my diamond ringe which I had of Queen Anne." In $16 \mathrm{I}_{4}$ he is entered as "Peter Chamberlen (sic) surgeon

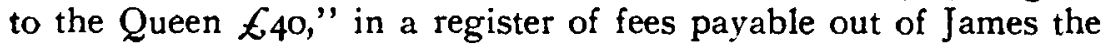
First's exchequer. In 1627 he was awarded $€ 600$ for undertaking 
the duties of Duncan Primrose, Sergeant Surgeon to Charles I, during his absence ( $I b$., pp. 6 to 9 ).

1616. The College of Physicians deliberate about letters patent for the incorporation of midwives, the midwives' petition being considered. "To Peter Chamberlen the younger, who was impudently advocating the cause of these women, the question was put, whether, if a difficulty in a case of labour were propounded to any member of the College he would not answer and judge more correctly than any obstetric surgeon whatever, in spite of his boast that he and his brother, and none others, excelled in these subjects" (lb., p. 29). The College did not " think yt neither necessary nor convenient that they (the midwives) should be made a corporation to govern within themselves a thinge not exampled in any commonwealth" (Ib., pp. 23, 24, see 1634).

16rg. Dr. Peter Chamberlen graduated as Doctor of Medicine at Padua, when only eighteen years of age.

1620. Dr. Peter Chamberlain was incorporated on the Padua degree at Oxford.

1620. Last entry of the name of Peter the younger in the Annals of the College of Physicians. After Drs. Argent, Clement and Golston had charged him with adding the pulp of colocynth to a clyster which they had prescribed for a male patient, they accused him of other instances of evil practice in the cases of puerperal women to the number of three, four, or five (Ib., p. 25).

162I. Dr. Peter Chamberlen was incorporated on the Padua degree at Cambridge. Examined by the Censors of the College of Physicians and "recommended to wait and try again with good expectation of success the next time."

1626. Dr. Peter Chamberlen examined once more, at the College of Physicians, approved, elected and sworn.

Death of Peter Chamberlen the younger at Downe, Kent.

1628. Dr. Peter Chamberlen admitted Fellow of the College of Physicians April 7, after being admonished to " no longer follow the frivolous fashion of the youth at Court " $(I b .$, p. 32).

I628. Peter Chamberlen the elder appears as a court obstet. rician. "The Queen (Henrietta Maria) mis-carried of her first child. She had neither mid-wife nor physician about her, only the poor town mid-wife of Greenwich was sent for who swooned with fear as soon as she was brought into the Queen's chamber so as she was forced presently to be carried out; and Chamberlayne (sic) the surgeon was he alone that did the part of a midwife. This took place in 1628." "Court and Times of Charles I," quoted by Aveling, $O p$. cit., p. 9. (See I663 and 1682.)

1630 (or a year or two earlier or later). Birth of Dr. Hugh Chamberlain the elder, son of Dr. Peter. No proof that he ever took a degree. 
I631. "Peter Chambrelan thelder of London Chirurgion" died, probably at Downe in Kent (Aveling, l. cit., pp. 9 to I4). Probably the inventor of the "saving" midwifery forceps. (See Ib., p. 226.)

1634. Negotiations with the College of Physicians for the establishment of a Corporation of Midwives with Dr. Peter Chamberlen as Governor. The scheme was disapproved of by the College and by the Archbishop of Canterbury (Laud) and the Bishop of London (Juxon) (reported in full, Aveling, loc. cit., p. 34 et $s e q$ ).

It was objected that Dr. Chamberlane (sic) practised midwifery " as a Physitian" and should have nothing to do with midwives than "other of the Physitians of the College have whose advice they crave when occasion requyres it and whose Judgem ${ }^{\text {ts }}$ no doubt are as good as his in any accidents that may befall or concerne women $w^{\text {th }}$ childe vnles itt be in the very act of deliv'ie of vnnaturall and dangerous births to effect $w^{\text {ch }}$ there is necessitye of using of instrum ${ }^{\text {ts }}$ of iron, being indeed more pperly the work of a Surgeon then a Physition; so with manuall practize the said Dr. hath applied himself more than others by reason few or none can brook the practise thereof."'1

This document proves that as early as in 1634 the profession was well aware that the Chamberlens used special "instruments of iron," so that they must already have been in use for many years.

1635. Birth of Paul, son of Dr. Peter Chamberlen. He practised midwifery but became an avowed charlatan.

Dr. Peter Chamberlen visited the "Low-Countreys." Reported in the books of the College of Physicians as an absentee. Several charges of professional irregularities are recorded during this period of his life. Thus in 1634 and 1638 there were complaints that he kept a French apothecary in his house.

I642. Sir John Hinton, once associated with Dr. Peter Chamberlen, attended Queen Henrietta Maria at Exeter when she gave birth to the Princess Henrietta, afterwards Duchess of Orleans.

1647. In "The Ladies' Parliament" by Henry Nevill, 1647, is to be found the following order of the House : "That Dr. Hinton and Dr. [Peter] Chamberlen be likewise assistants that with greater secrecy and ease their Ladyships may be help and with their most troublesome and pressing affairs" (Aveling, ib., p. 32).

1. In a communication on "The Curves of the Midwifery Forceps," Trans. Obstet. Soc., Lond., Vol. XX (1878), p. 132, Aveling quotes a later reference, "circa 1640," about Dr. Peter and his iron instruments. But Aveling's standard work was published four years later, and the above quotation proves that the "instruments" were well known in 1634, when the "Bishopp" gave audience to the petitioners on September 4th. 
Publication of "A Voice in Rhama," Dr. Peter Chamberlen's reply to the accusations of the physicians and midwives who had condemned his project for the incorporation of midwives. He speaks of the "common knowledge" of "Asclepiad families" and defends the principle of keeping secret new remedies and operations introduced by such families.

Fined by the College " concerning the making of his feast," that is, for not giving the customary dinner to newly admitted Fellows (Ib., p. 6o).

1649. Dr. Peter Chamberlen's bath and bath stove scheme, approved by the House of Lords, strongly opposed by the College. He ceased to attend its meetings, and on November 23rd was dismissed from the Fellowship (Ib., p. 77).

1650. Palfyn born at Ypres. Publication of "An Answer to Dr. Peter Chamberlaine's (sic) Scandalous and False Papers" by Philolethes. A scurrilous but amusing biography and criticism of Chamberlen (Ib., p. 33).

[During the Commonwealth Dr. Peter Chamberlen entered into numerous religious disputations.]

I66o. Dr. Peter Chamberlen appointed Physician in Ordinary to Charles II. (appointment confirmed 1672.) He behaved very strangely during the rest of his life.

1663. December I9th "Le Sieur Boucher" attends Mademoiselle de la Vallière in her first confinement. [Julien Clément, the first recognized accoucheur to a court, was only 14 years old at that date. The Princesse de Conti, the eldest of the La Vallière's children who survived, was born in 1666. See Cabanès, "Le Carnet Secret de l'Histoire," 2me Serie, p. 39 et seq.]

1664. Birth of Dr. Hugh Chamberlain, Junior.

1668. According to R. W. Johnson (see 1769), Drinkwater of Brentford already began to use in this year a forceps which came into Johnson's possession.

1670. Julien Clément (see 1663), afterwards Court Accoucheur, attended Mme. de Montespan at the birth of the Duc de Maine, on March $3 \mathbf{I}$.

Hugh Chamberlen, senior (who had taken an active part in the plague year 1665) visits Paris, and fails to deliver Mauriceau's patient, a rachitic dwarf, aged 38 , who dies " après les extrêmes violences qu'il lui avoit faites." (" Observations sur la Grossesse et l'Accouchement," Case xxvi, published in full, in the original French, by Aveling, loc. cit., pp. 128 to 132. .)

1672. Hugh Chamberlen's translation of Mauriceau's work on Midwifery published.

1673. Hugh Chamberlen appointed Doctor in Ordinary to Charles II. vice Sir John Hinton, deceased.

1681. Hugh Chamberlen, Senior, elected (as “Dr. Hugh 
Chamberlain") a Fellow of the Royal Society, and registered "Chamberlane" when admitted (Aveling, loc. cit., I30, footnote).

1682. Clément's first case as Court Accoucheur (birth of the Duc de Bourgogne, eldest child of the Dauphin and the Dauphine Marie Anne de Bavière). See 1628 .

1683. Death of Dr. Peter Chamberlen at Woodham Mortimer Hall, Essex. The forceps, etc., were discovered there in 1818 , and are now in the library of the Royal Society of Medicine.

1684. Hugh Chamberlen, Junior, settled at Leyden.

1685. Hugh Chamberlen, Senior, publishes, avowedly for the use of a son whom he had sent to the East Indies, his "Manuale Medicum or a small treatise of the Art of Physick in general and of Vomits and the Jesuit Powder in particular, by Hugh Chamberlain (sic), Physitian in Ordinary to His late Majesty and Fellow of the Royal Society, London." His advocacy of vomiting offended the College of Physicians (Aveling, loc. cit., pp. 138, 139).

1688. Hugh Chamberlen, Senior, prosecuted by the Censors for malpraxis. He had administered to a Mrs. Willmer, six months pregnant and suffering from pleurisy (?), four vomits, four purges and three bleedings (to $8 \mathrm{oz}$. each time) within nine days, then he salivated her freely and she miscarried and died.

1688, June 10. Birth of James, the "Old Pretender" or Chevalier de St. Georges. Dr. Hugh Chamberlen, Senior, was sent for " and found a child newly born loose and undrest, in Lady Powis her lap, and as I was informed, brought forth an hour before I came." Letter " to the Princess Sophia" about the warming pan legend. See Aveling, loc. cit., p. I 49.

1689. Hugh Chamberlen, Junior, created M.D. Cantab (Comitiis Regiis).

I69o. Dr. Hugh Chamberlen, Senior, publishes a "Proposal to make England Rich and Happy" by a Land Bank. For ten years he agitated and a great number of pamphlets written by himself and his supporters and opponents were published during that space of time (see Aveling, loc. cit., p. 154, et seq, and Macaulay's " History of England," vol. iv).

1692, April 17. "Dr. Chamberlain (sic) had the honour to lay the Princesse (Anne of Denmark, afterwards Queen Anne) of a Son who immediately dyed. He had a hundred guineas for his pains." Letter quoted by Aveling, loc. cit., p. 15I. The doctor was Hugh Chamberlen, Senior.

Birth of Mary Louisa when her mother, Queen Mary of Modena, was in exile at St. Germains. James II. had sent for Dr. Hugh Chamberlen, Senior, but a pass was refused to him.

1693. Dr. Hugh Chamberlen, Junior, examined and admitted "Candidate" (equivalent to M.R.C.P.) at the College of Physicians. In the same year he brought about the prosecution of Cort, 
a surgeon who had prescribed "internall medicins" for one of Chamberlen's patients (loc. cit., p. I88).

1694. Dr. Hugh Chamberlen, Junior, admitted a Fellow of the College of Physicians. He was chosen Censor in 1707, 17 19 and I 72 .

1694. Hugh Chamberlen, Senior, publishes "A few Queries relating to the Practice of Physick," including a repetition of his arguments in favour of vomits and a proposal for "a new Establishment of Physick," which, among other things, was to " reform the practice of Midwifery" (loc. cit., p. 152). The scheme fell to the ground.

1699. "Tuesday, 2 I Mar. Dr. Chamberlain (sic), the manmidwife, and manager and sole contriver of the Land-bank, is retired to Holland, on suspition of debt" : a scurrilous "Hue and Cry after a Man-Midwife, Who has lately delivered the Land Bank of their Money" appeared shortly afterwards. "From that time all trace of Hugh Chamberlen, Senior, in this country is lost" (Aveling, loc. cit., p. I 7 I).

I 700. John Chamberlen's will proved on January 6th, but the actual date of his birth and death is lost. He was a son of Dr. Peter and, like his brothers Hugh, Senior, and Paul, he practised midwifery and possessed the family secret.

1702. Hugh Chamberlen, Senior, wrote (in Holland or possibly in Scotland) a pamphlet advocating the Union with Scotland. He practised afterwards in Amsterdam, and sold the family secret of the forceps to Roonhuysen.

1706. Paul Chamberlen (so spelt in his signature) writes a letter to Sir Hans Sloan about a midwife (loc. cit., p. 183).

I7 I0. Swift, in his journal to Stella, letter viii, Nov. 5, refers to "Dr. Chamberlain." Burton (" Dr. Slop ") born at Colchester.

17ı. Death of Paul Chamberlen. (Aveling, loc. cit., p. I83. At least it is known that his will was proved on December I9th. It was dated by P. Chamberlen, May 24, 17 13.)

I7 18. Hypothetical date of birth of "Tristram Shandy" (Bk. III, Chap. 3). Burton, or "Dr. Slop," was only a year old at this date.

1720. Palfyn exhibits his mains de fer before the French Académie Royale des Sciences. Smellie in practice in Lanark. Dr. Hugh Chamberlen, the elder, mentioned as living, in a legal document. He was apparently in Holland. The date of his death has been lost.

I721. Tobias Smollett born. De la Motte in his "Traité complet des Accouchements " denounces secrecy about obstetrical instruments, specially mentioning a "certain surgeon from Ghent who had exhibited his forceps at Paris,"-meaning Palfyn. 
I723. The Faculty of Paris declare its approbation of Palfyn's forceps.

1724. Heister of Helmstadt first figured Palfyn's forceps from a sample lent to him by a friend (Mulder, "Historia Forcipum," p. I6). The passage is somewhat obscure :- "Verum enim vero Cl. Laurentius Heister, in Academia, quæ Helmstadii est, olim Professor, qui primus, quantum novi, Cochlearia Palfyni depingenda curavit ab ipsa specimina (sic), quæ amicus quidam cum Illo communicaverat, diversam a Levreti, Windiique descriptionibus delineationem dedit, sed hanc verum ipsius Palfyni Instrumentum referre propter allatas rationes credere vix licet." 1 (Mulder, " Historia Forcipum," I 796, p. 16.)

"For indeed truly Cl. Laurence Heister (late Professor in the University which is at Helmstadt, who first, as far as I know, had 'Palfyn's Forceps' drawn from the very specimen which a certain friend had shown him) gave a drawing different from the descriptions of Levret and de Wind; but one can hardly believe that this (drawing) refers (to) Palfyn's instruments for reasons given."

I 726. Date of first case (No. xiv) where Giffard distinctly states that he made use of his forceps (see I 734).

Sir Richard Manningham (see "Tristram Shandy," Bk. I, Chap. xviii, "As the famous Dr. Manningham was not to be had ") exposes Mary Tofts the rabbit-breeder in "An exact Diary of what was observed during a close attendance upon Mary Tofts, the pretended Rabbit Breeder of Godalming from Nov. 28 to Dec. 7 together with her confession of the Fraud."

1728. Death of Hugh Chamberlen, junior. "DeathsMonday night last died Dr. Chamberlain, a famous Physician and Man-Midwife of the gout in his stomach." London Journal, June 22.

"The eminent physician and Man midwife, Dr. Hugh Chamberlen, who died on Monday night was grandson of the famous Dr. Peter Chamberlen who with his father and uncles were physicians to King James I, King Charles I, King Charles II, King James II and King William, to their respective Queens and to Queen Anne. $\mathrm{He}$ was the last of that Ancient Family who

1. According to more than one classical authority, Mulder's Latin was very faulty and unintelligible. Dr. David Davis speaks of his "barbarous" Latin in reference to Mulder's notes on Rawlin's forceps ((see 1793) ("On the Craniotomy Forceps of Dr. Davis in Reply to Mr. Rawlins of Oxford," Lond. Med. Repository, Vol. VIII, 1820 , p. 381). I am indebted to Sir Francis Champneys for perusing some of Mulder's text and for the translation of the above passage. Mulder's "Epicrisis Forcipum," a summary of the instruments which he describes, with comparisons between them, and his own opinion about them, should be studied before the reader in turn judges Mulder. It forms the concluding part of the "Historia Forcipam." 
practised the Art of Midwifery in the Kingdom except Dr. Walker ${ }^{1}$ in Great Suffolk Street who is a Grandson to the fore-mentioned Dr. Peter Chamberlen." ("Country Journal and the Craftsman," June 22, I728; quoted by Aveling, loc. cit., p. 193.)

Death of Drinkwater of Brentford (see I668).

1730. Death of Palfyn. Paulus de Wind studied at Leyden.

1733. Address on prenatal baptism by syringe presented by a surgeon to the Sorbonne, "Tristram Shandy," Bk. I, Chap. xx, and taken from a report by Deventer.

Butter exhibits a sample (see 1734) of Dusée's forceps at Edinburgh : report is preserved in "Medical Essays and Observations : Revised and published by a Society in Edinburgh," vol. iii, p. 322 (2nd edition, published 1737). A double-jointed forceps with pivot removable so as to fit either joint. No other two-jointed forceps is figured or noted in Mulder's work. Nor is any such forceps represented in either of Kilian's atlases excepting that designed by Thureaud of New Orleans in the Igth century; its blades were reversible as in Tarsitani's and Rizzoli's forceps.

First edition of Chapman's "Essay on the Improvement of Midwifery." No drawing of his forceps (see 1735). Chapman mentioned in this edition how he fashioned a movable screw, and losing it at a delivery found that his forceps acted "much better" without it. That was really the origin of the English lock, perfected by Smellie. There is no evidence that Smellie had ever used the forceps at this date (1733), and McClintock believes that Chapman's example inspired him (loc. cit., vol. i, p. r 58 ).

Dr. Burton (" Dr. Slop "), St. John's College, Cantab, took the M.B. degree and began practice at Heath, near Wakefield.

Freake's forceps or "extractor" in use (see 1734).

1734. Death of Dusée, when De Wind was a pupil in his house (De Wind "'t Geklemd Hoofd geredit." See $175 \mathrm{I}$; also Doran, "Dusée : His Forceps and his Contemporaries," Journ. of Obst. and Gynacol. of Brit. Empire, I19, and "Dusée, de Wind and Smellie," $i b ., 203$ ).

Dr. Hody, F.R.S., publishes "Cases in Midwifry (sic): Written by the late Mr. William Giffard, Surgeon and Man Midwife" (see 1726). Hody dates his preface "July 30, 1733"; his title page bears the date 1734 . Hody figures not only "Mr. Giffard's Extractor," but also "The Extractor as improved by Mr. Freke, Surgeon to St. Bartholomew's Hospital," without any

r. The date of Dr. Walker's death is unknown. Dr. William Douglas blamed Walker for spoiling the Chamberlain forceps by giving it a male and female blade. A sample of Walker's forceps is preserved in the Edinburgh Obstetrical Museum (Sir A. K. Simpson's "Invention and Evolution of the Midwifery Forceps," Scottish Medical and Surgical Journal, Dec. 1900). 
mention of it in the text. No note of it by Freke himself is extant. It was the first forceps with jointed handle like Saxtorph's. See Doran, "Jointed Obstetric Forceps," Journ. Obst. and Gyn. Brit. Empire, vol. 24, p. 198.

Sir Miles Stapylton (Tory) elected a county member for Yorkshire largely through Dr. Burton's exertions. Great opposition from Sterne and his uncle who henceforward persecuted Burton.

I 735. Second edition of Chapman's " Essays," published with a figure of his forceps (see 1732), and his Apologia (quoted in "Dusée: His Forceps and his Contemporaries," p. r31). He admits that he was wrong in not publishing "a Figure of my Forceps" in his first issue and therefore he now adds "an exact draught of it."

1736. John Douglas (see 1743) published his "Short Account of the State of Midwifery in London, Westminster, \&c." $\mathrm{He}$ advocated the better training of midwives, objected to male obstetricians, and blamed Chapman for keeping his forceps secret for so long.

"Incogniti" the second, a forceps with the English lock published. See Mulder, loc. cit., P1. II, 4 and 5, and pp. 22, 23, where $\mathrm{Du}$ Pui states that this instrument was far superior to Chapman's.

[For observations on the discrepancy about Mulder's forceps marked "Incogniti," see " Dusée : his Forceps," \&c., p. 138.]

Smollett enters Glasgow University as a student. Apprenticed to a surgeon.

An "Account of a Monstrous Child," by Dr. Burton, appeared in the Edinburgh "Medical Essays and Observations" (see 1733) for this year. It was a case of ectopia vesicæ.

1737. Smellie made use of Dusée's forceps and rejected them ("Treatise," McClintock's ed. MSS., Case 281, vol. ii, p. 375). Hence McClintock infers that Smellie had little, if any, experience of the forceps at that date.

Chapman published a Reply to Douglas' "Short Account" (see 1736).

Death of Guillaume Mauquest de la Motte. An adversary of Palfyn and disbeliever in the forceps. He was a great advocate of podalic version.

Manningham (see 1726) establishes a private lying-in home.

1738. Burton published his "Treatise on the Non Naturals."

Laurence Sterne ordained priest. Four days later made Vicar of Sutton-in-the-Forest, eight miles from York. Held the living till I 759 .

1739. Smellie (born 1697 in or near Lanark) came up to London.

Smollett appointed surgeon to a King's ship. 
Sir Richard Manningham publishes his "Artis Obstetriciæ Compendium tam theoriam quam praxin spectans."

I740. York County Hospital founded by Dr. Burton and his Tory friends; the Whigs opposed its establishment.

Pugh first used his forceps with pelvic curve about this year (see 1754 ).

I74I. William Hunter came up to London and lived with Smellie.

Mesnard's tenettes à cuiller, which had blades that did not cross, reported by the inventor in the "Journal de Verdun."

Burton again assists in the election of the Tory County Member for Yorkshire, against Sterne's candidate (see 1734).

I742. Smellie's "Treatise on the Theory and Practice of Midwifery " first appeared as " A Collection of Cases and Observations in Midwifery."

1743. Mesnard describes his forceps in "Le guide des accoucheurs ou le Maistre dans l'art d'accoucher les femmes." Blades somewhat like Palfyn's, united by a chain.

John Douglas died (see I736). His life was published by G. T. Bettany.

I744. Manningham's "Abstract of Midwifery for the Use of the Lying-in Infirmary" published.

Smollett, having given up the Navy, settled in Downing Street, Westminster.

Smellie introduced his special lock. "In his letter to Mr. John Gordon, surgeon, at Glasgow, dated Jan. 12th, 1747-8," Smellie says: "About three years ago I contrived a more simple method of fixing the steel forceps by locking them into one another by which means they have all the advantages of the firmer kind without their inconveniences." Smeilie, loc. cit., McClintock's ed., vol. i, p. 21. The letter was included in the answer to Dr. W. Douglas's first pamphlet.

1745. The Surgeons separate from the Worshipful Company of Barber Surgeons.

Smellie receives degree of M.D. Glasgow.

Burton arrested in York, suspected of complicity with the Young Pretender.

I 746. Boehmer of Halle (I7I7-i 789) translated Manningham's "Artis Obstetriciæ Compendium" (see 1726 and I729), to which translation Mulder adds, loc. cit., p. 25, "Gregorianæ forcipis delineationem simul et descriptionem satis accuratam subjunxit." Boehmer, in the appendix to this translation, headed "De Usu et Præsentia Forcipis Anglicanæ," describes Grégoire Junior's forceps of which no account by the inventor is known.

Smellie used his own short forceps and failed to deliver with 
them (Case 38I), its handles not yet "altered from crooks to wooden handles as I now ( 1751 ) have them."

Burton conveyed early in the year to London.

1747. Levret brings before the Paris Academy his forceps with la nouvelle courbure and describes it in his "Observations sur les causes et les accidens de plusieurs accouchemens laborieux" published in the same year; he also figures his forceps with the curve (see 1749 and 1751 ).

Rathlauw designed his forceps, but was forbidden to practise in Amsterdam, as he was not acquainted with the secret of Roonhuysen which the latter had bought of Hugh Chamberlen, Senior, who had retired to Holland and died there, at a date which has been lost. Rathlauw published "Het berugt geheim in de Vroedkunde van Rogier Roonhuysen outdekt en uitgegeven op hooge order door Jan Pieter Rathlauw, Vroedmeester" (Amst., 1747), exposing, as he believed, the secret. The proprietors of the secret, five obstetricians of Amsterdam, at once published a reply denying that Rathlauw had revealed any secret (see I754, and Mulder, loc. cit., p. 28). Rathlauw's forceps was, unless Schlichting's was of older date, the first which, like Assalini's, had its joint at the free end of the handle; his first pattern was not fenestrated, but he also described in his pamphlet another pattern with fenestrated handles, and the shank of one blade passes through that of the other.

Schlichting, in the same year, 1747, publishes his " Embrylucia nova detecta," and describes and figures a forceps very similar to Rathlauw's first pattern, having no fenestræ, and a joint as in Assalini's much later and better known instrument. He ascribed its invention to Brederode or Ruisch. (See Mulder, loc. cit., p. 32.)

Burton discharged from his imprisonment in London (in March).

1748. William Hunter elected one of the surgeon menmidwives to the Middlesex Hospital, and soon after to the British Lying-in Hospital.

1749. An anonymous critic writes against Levret's forceps in the "Journal des Sçavans" (August), saying that the instrument was well-known but that nobody had ever had a single opportunity of using it (see $175 \mathrm{I}$ ).

Burton publishes his " British Liberty Endangered," dedicated to the Archbishop of Canterbury, Thomas Herring, in which he reports how he was persecuted by his political enemies.

1750. First notice of Bing's forceps, Janck publishing at Teipzig his "Commentatio de forcipe ac forfice ferramentis a Bingio inventis, eorumque usu in partu difficili" (see I75I).

Tobias Smollett obtains in June the degree of M.D. from Marischal College, Aberdeen. 
1751. Levret, in reply to his critic (see 1749), publishes his "Suite des observations sur les causes et les accidens," \&c. (see 1747), reporting a case where his forceps was successfully used, the head presenting.

Smellie described his curved forceps in the same year. His "Essay on Midwifery," dated 1752, was issued in the previous year, being noticed in the "Monthly Review," December, I75I. Smellie already used forceps with wooden handles instead of crooks (see 1746), and Dr. William Douglas objected to the wooden forceps. In Case 269 Smellie " now substituted steel covered with leather in the room of wood which is not so durable." This is the only occasion on which he speaks of this short forceps, but there is no date. (McClintock, op. cit., vol. i, p. 258.)

Paulus de Wind publishes " 't Geklemd Hoofd geredt," relating his association with Dusée (see 1734) and describing his own forceps, the blades of which were solid and completely separate, having no joint or lock, nor were they made to cross. See "Dusée, de Wind and Smellie : an Addendum," Journal, vol. xxii (Igra), p. 203. Mulder (loc. cit., p. 4I and footnote) states that there was no date on the title page of this work, but that it came out about 1752. Professor Kouwer possesses a copy dated 1751 .

Jens Bing, born in 1681 at Drontheim, Norway, died in Copenhagen, where he had a large practice and invented his forceps, non-fenestrated, and with long handles made to be detached. The object was the application of the blades with as little exposure as possible. Levret, in his "Suite des Observations," \&c., condemns Janck and Bing for this alleged advantage in the "forceps de Bingius."

Publication of Burton's "Essay towards a Complete new System of Midwifry." This is the "five shilling book upon the subject of midwifery" mentioned in "Tristram Shandy," Bk. I, Chap. xviii. His forceps had been already in use. He rightly condemned Smellie's practice of wrapping the blades in leather. See "Burton ('Dr. Slop'), his Forceps and his Foes," Journ. Obst. and Gyn. Brit. Empire, vol. 23, 1913, p. I.

1752. Smellie, in Case 315, after-coming head, found that the short straight forceps was useless and made use of a longer curved instrument.

Smollett set up practice in Bath.

1753. In Case 352, Smellie completed delivery by the employment of a long double-curved forceps. "They were contrived some years ago by myself as well as other practitioners on purpose to take a better hold of the head when presenting and high up in the pelvis; but I did not recommend their use in such cases for fear of doing more harm than good by bruising the parts of the 
woman when too great force is used." But Smellie had described his curved forceps in 1751 (see 1751 ).

Burton publishes his "Letter to William Smellie, M.D., containing Critical and Practical Remarks upon his Treatise on the Theory and Practice of Midwifery by- John Burton, M.D. Wherein the various Gross Mistakes and dangerous Methods of Practice mentioned and recommended by that Writer are fully demonstrated and generally corrected," \&c.

1754. Pugh, of Chelmsford, publishes his "Treatise of Midwifery," and speaks of "the forceps I invented upwards of fourteen years ago" (see 1740).

Rathlauw writes again on Roonhuysen's secret in reply to a violent attack on him, published at Amsterdam earlier in the same year. (Mulder, op. cit., p. 29.)

On March I Smollett wrote to Dr. J. Moore showing that he had revised the second volume of Smellie's work. See Glaisher, "Smellie and his Contemporaries," Glasgow, I 894.

1755. In a case where the feet and hands presented, Smellie brought down the body and then delivered the head with doublecurved forceps.

1756. Death of John Freake. He was born in London in 1688, elected assistant surgeon to St. Bartholomew's Hospital and full surgeon in 1729 , when he became a F.R.S. He resigned in I755 on account of gout and other infirmities. See Wadd's "Nugæ Chirurgicæ" and MSS. St. Bartholomew's Hospital Official Records.

Sir Richard Manningham's "Aphorismata Medica," the second edition of his "Artis Obstetriciæ Compendium" (see 1739) published.

1758. First volume of Burton's Monasticon appeared (the second was never published).

1759. Smellie retired from practice and went home to Lanark.

First part of " Tristram Shandy" said to have been published, or printed at least, at York (very doubtful). Johnson's "Rasselas" and Voltaire's "Candide" both appeared in this year.

Osiander born at Zell unter Aichelberg, Würtemberg.

1760. First part of "Tristram Shandy," including satirical sketch of Burton as "Dr. Slop," published in London.

1763. Death of Smellie, aged 66; he was interred in the burial ground of St. Kentigern's Kirk near Lanark.

1767. Stein, independently of other writers, notes how Levret modified his forceps more than once. (Mulder, op. cit., p. 46.)

1768. Death of Sterne, March I8th (b. Nov. 24, 1713).

1769. R. Wallace Johnson, inventor of the perineal curve, published "A New System of Midwifery," where, according to 
Aveling (" The Curves of Midwifery Forceps," Trans. Obst. Soc., vol. $x x, p .144)$ this new curve is first mentioned.

1770. Fried's forceps probably first used (see 1771).

Fourth edition of Levret's "Observations" and "Suite des Observations," published together. The drawing in the earlier editions in the first part, representing the three-bladed forceps and the two-bladed forceps with axe ambulant, is reproduced, and the forceps à courbe, with a simple lock, is represented in the Suite.

1771. Fries, a pupil of Fried's, describes Fried's forceps in his Disseriatio de usu forcipis in partu. "It has Levret's blade and Smellie's handle and lock." Mulder believed that the arrangement by which one handle moved by aid of a screw on its own axis was suggested by Frère Jean de Come's lithotomy forceps (op. cit., p. 55).

Smollett dies in his estate. Francis Drake, Burton's surgical colleague, dies at Beverley.

1774. Leake, of the Westminster Hospital, in his "Lecture Introductory to the Theory and Practice of Midwifery, including the Description and Use of a New Forceps," publishes an account of his three-bladed forceps (see Denman, 1783). J. L. Petit's forceps, "already long in use" (Mulder, op. cit., p. 57), first described and figured in Lesne's Traité des maladies chirurgicales et des opérations qui leur conviennent. Admittedly a modification of Grégoire's instrument, it has a catch on one handle with teeth on the opposite side, to regulate the pressure on the fœtal head during extraction.

1776. In a copy of Schlegel's translation of Mulder's work once left by Dr. Rigby to the Obstetrical Society of London and now in the library of the Royal Society of Medicine, Rigby marks in pencil, p. 8o-" "My manuscript copy of Lowder's lectures is 1776" (see 1783).

1777. Van de Laar describes his forceps " Schets der geheele Verloskunde geschikt om derselver grondbeginzels volkomen te leeren." 's Gravenhaage, 1777. Van de Laar introduced axis traction, this year, by drawing directly from the blades by means of a rod, which was straight. In $1844 \mathrm{~T}$. Homann devised a straight rod; in 1877 Tarnier introduced curved axis tractors. See Katherine Drinkwater, M.B., "The Midwifery Forceps : Historical Sketch,"Liverpool Med. Chir. Journ., July 1913, p. 451. For Van de Laar's forceps see Mulder, op. cit., p. 59, and pl. vi, figs. II and I 2.

Coutouly junior's forceps described by Catalan in the " Journal de Paris," Dec. 6; it closely resembled Levret's forceps (see i 788 ). (Mulder, op. cit., p. 60.)

I 781. Péan's forceps adopted by J. L. Baudelocque in his Art 
des Accouchemens. See 1789 and Note 2, "The Baudelocque Family."

1782. Lowder, in M.S. lectures on the "Theory and Practice of Midwifery" (Lib. Royal Soc. Med), mentions Orme as modify. ing Smellie's forceps. See Doran, "A Demonstration of some Eighteenth Century Obstetric Forceps," Proc. Royal Soc. Med., 1913, vol. vi, Sec. History Med., p. 54.

I783. Sleurs describes his vectis and a double vectis making a forceps, in his "Vroed en werktuigkundige proefnemingen waar door de Hefboom verbeterd en deszelvs gebruik, tot redding van de geklemde of door de beenderen des bekkens opgehoudene hoofden, uitgestrekter en veiliger gemaakt word," a pamphlet published in this year in Utrecht.

Denman publishes an anonymous pamphlet on Leake's three. bladed forceps: "A Vindication of the Forceps described and recommended by Dr. Leake; by a Late Pupil of Dr. Leake's." (See 1774.) Osborn's forceps is mentioned, p. 19.

Carl Gottlob Kühn publishes the first printed account of Orme's and of Lowder's forceps in a thesis, reprinted in 1827 with his other works under the title "Opuscula Academica Medica et Philologica."

1784. Young of Edinburgh's forceps, of the R. Wallace Johnson type (see 1769), mentioned in the edition of Smellie's Midwifery published this year, vol. iii, fig. 40 .

Evans of Oswestry's forceps, also of the R. W. Johnson type, likewise described in the same edition of Smellie's work. The blades had the double Johnson's curve and did not diverge imme. diately above the lock but ran straight and parallel for some distance. Hence Evans' forceps is the prototype of Simpson's and similar instruments invented in the nineteenth century, where there is a gap between more or less parallel and straight shanks, modified as a ring in Hopkins' and, later, in Barnes' forceps.

First edition of Aitken's " Principles of Midwifery or Puerperal Medicine." He mentions his modified lock.

1785. Mayer writes on Levret and modifies his forceps.

Second edition of Aitken's "Principles," includes a drawing of his forceps applied to the after-coming head.

Starke of Jena's forceps described by his pupil, Döbner (Mulder, loc. cit., p. 74).

1786. Third edition of Aitken's "Principles." Besides the graduated lock there was a wide space between the shanks of the blades for the obstetrician's middle finger, while there was a blunt knob on the upper border of each handle, close to the lock on which the fore and ring fingers rested. ("By this disposition the mother's parts are fully protected.") The knobs did not correspond to the flanges or finger rests (see 1796, and Doran, "Eighteenth Century 
Forceps," " 17 th International Congress, 1913, Section 23, History of Medicine," p. 454).

1788. Coutouly's modification (see 1777) made known by Mithof in his " Nouveaux Forceps, presentés à l'Académie Royale de Chirurgie, à la séance publique en I788, M. Coutouly" (Mulder, op. cit., p. 77).

1789. J. L. Baudelocque admits of priority of Péan in design of forceps named Baudelocque's (see $178 \mathrm{I}$ ). See Mulder, op. cit., p. $6 \mathrm{r}$.

I 791. Matthias Saxtorph publishes a paper at Copenhagen on his forceps (see Mulder, op. cit., p. 81), with handles made to fold on the blades. A similar forceps, Levy's modification, was still used in Denmark in 1866 . See "Catalogue and Report of Obstetrical, etc., Instruments exhibited at the Conversazione of the Obstetrical Society of London, i866," p. 95.

1792. Osborn's "Essays on the Practice of Midwifery" published. It included a drawing of the author's forceps with measurements, but the instrument is more fully described in Mulder's "Historia Forcipum," p. 82, and pl. vi, figs. 5 and 6. Osborn's and Saxtorph's forceps were short, yet had a pelvic curve like in Levret's long forceps.

Thynne, about this year, introduced a similar forceps, of the same length as Osborn's but with longer blades and therefore shorter handles. See Mulder, "Historia Forcipum," pl. vi, figs. 9 and I0, p. 85. " Doct. Thynne, Prælector etiam Artis Obstetriciæ Londiniensis." A manuscript copy of notes from Dr. Thynne's lectures (Lib. R.C.S. Eng.) contains no mention of his forceps which Mulder copied "ab ipsa instrumenta."

Dr. G. Rees dedicated his "Observations on Diseases of the Uterus" (1805) to Thynne as a leading authority.

1793. Denman publishes his "Aphorisms on the application and Use of the Forceps and Vectis" (Mulder, loc. cit., p. 84 and footnote, pl. vi, figs. 7 and 8 ).

Hamilton's jointed forceps first described in Andrew Duncan's “ Medical Commentaries" for 1793, decade 2, vol. viii, p. 405. See also Doran, " Jointed Forceps," Journ. of Obst. and Gyn. of Brit. Empire, vol. 24 (1913), p. 204.

Rawlins, of Oxford, publishes "A Dissertation on the Structure of the Obstetric Forceps, pointing out its defects, and especially of those with Double Curved Blades." Rawlins' work gained the approval of Mulder who describes the forceps and figures the "Brachium forcipis Rawlinsil" (loc. cit., p. 160, and pl. xi, pp. 3 and 4). Nearly thirty years later David Davis attacked Rawlins, and commented unfavourably on Mulder (see above, 1724, footnote).

1794. Mulder's “Historia Litteraria et Critica Forcipum et Vectium Obstetriciorum" published at Leyden. See I798. 
1796. Johann David Busch publishes his “Beschriebung einer neuen Geburtszange, nebst einigen Beobachtungen über ihre Anwendung " in Stark's Archiv für die Geburtshülfe, etc., vol. vi, pt. 3. It is the first instrument that bore flanges or finger rests, adopted by Naegeli and Simpson afterwards, and constructed with joints by Stoltz (1839) and Levy (1866). See " Eighteenth Century Forceps," noted above under Aitken, 1786, p. 450.

1798. Schlegel's translation of Mulder's "Historia Forcipum" appears, under the title "Litterärische und Kritische Geschichte der Zangen und Hebel." He refers to Osiander as the introducer of the forceps coated with rubber (appendix, p. I 20), but makes no mention of that obstetrician's own forceps which were introduced about this year if not earlier. See "Mursinna: Osiander, Weissbrod. A Study of Forceps," Journ. of Obst. and Gyn. Brit. Empire, vol. xxiv, I9I3, p. 1. Mursinna probably made use of his forceps, first described in 1803 , before the end of the eighteenth century.

Note. I. The Chambelen Family.

From Aveling's "The Chamberlens and the Midwifery Forceps." William Chamberlen ${ }^{1}$

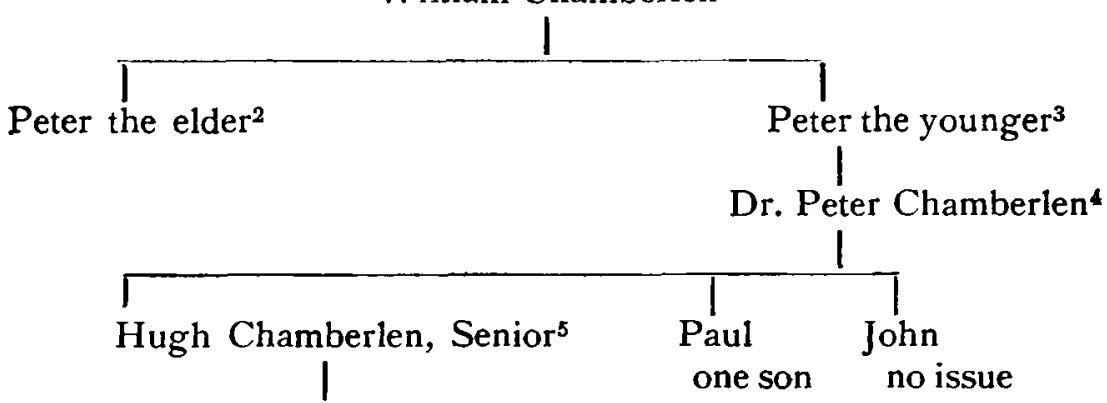

Hugh Chamberlen, Junior. ${ }^{6}$

Note. 2. The Baudelocgue Family.

Professor Paul Bar has kindly forwarded me the genealogy of this family, which was as obstetrical as the Chamberlens. They

I. He had two other sons besides the two Peters, and one daughter.

2. He had one child, a daughter, whose husband's name was Cargill; they had six children.

3. Beside Dr. Peter, Peter the younger had seven children, of which four were sons.

4. Besides Hugh C., Senior, Paul and John, Dr. Peter C. had six children, all but one of whom were sons.

5. Besides Hugh C., Jun., Hugh, Senior, had three children, two of whom were sons.

6. Hugh C., Jun., had one child, a daughter, by his first wife, and two children, both daughters, by his second, but none by his third wife, Lady Carew. The relationship of Walker's "grandson to the fore-mentioned Dr. Peter Chamberlain" (see 1728) is not made out in this table. 
have been traced to two brothers whose Christian names have not, I understand, been preserved.

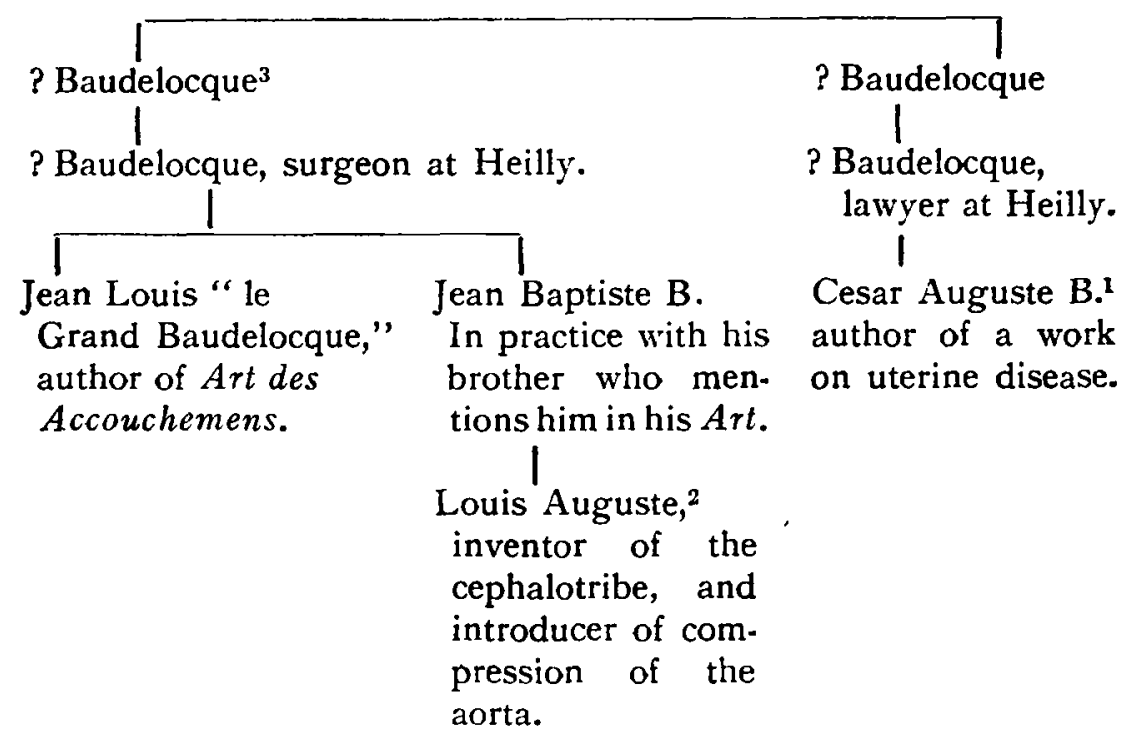

x. and 2. Louis Auguste and César Auguste are often spoken of as brothers, but this table shows that they were distant cousins.

3. "? " before four names in the above genealogical table means that the Christian name is uncertain. Jean Louis was the Baudelocque who approved of Péan's forceps (see $178 \mathrm{r}$ ). His brother, Jean Baptiste, took his part actively in his quarrel with Herbinaux. 